\title{
Leaf optical properties of two liana species Canavalia parviflora Benth. and Gouania virgata Reissk in different light conditions
}

\author{
MARIA CRISTINA SANCHES ${ }^{1,2}$ and IVANY FERRAZ MARQUES VÁLIO ${ }^{1}$
}

(received: February 24, 2005; accepted: June 29, 2006 )

\begin{abstract}
Leaf optical properties of two liana species Canavalia parviflora Benth. and Gouania virgata Reissk in different light conditions). Lianas are plants that depend on support to reach some appreciable height, and they represent an important structural component of tropical forests. Although they predominate in clearings and gaps, some species survive in the understory. Changes in irradiance between these environments can affect leaf morphology and absorption of photosynthetic active radiation (PAR). We had examined the effects of different light regimes on leaf optical properties, chlorophyll content, specific leaf area, and leaf surface morphology in young seedlings of Canavalia parviflora Benth. (Fabaceae) and Gouania virgata Reissk (Rhamnaceae). The seedlings were distributed on workbenches covered by different layers of neutral shade netting, thus creating three levels of light intensity corresponding to about $40 \%, 10 \%$ and $1.5 \%$ of solar irradiance. Plants growing in full sun were used as a control. Both species exhibited an increase in reflectance in full sun and alterations in leaf morphology. Reduction in irradiance induced an increase in absorptance (decrease in reflectance and transmittance) in $C$. parviflora leaves in the green due to higher chlorophyll content. In G. virgata the spectral leaf changes were less observable. However, the efficiency of absorption was more pronounced in G. virgata than in C. parviflora leaves under $40 \%, 10 \%$ and $1.5 \%$ photon flux density (PFD). The greater efficiency of absorption in G. virgata was due to a larger specific leaf area (SLA) under these conditions. The adjustments in leaf optical properties can aid these species in overall carbon gain under limited light conditions.
\end{abstract}

Key words - leaf absorptance, lianas, light conditions, reflectance, specific leaf area

RESUMO - (Propriedades ópticas foliares de duas espécies de lianas Canavalia parviflora Benth. e Gouania virgata Reissk, em diferentes condições de luz). Lianas são plantas que dependem de um suporte para atingir uma altura apreciável, formando um importante componente das florestas tropicais. Embora sejam dominantes em clareiras, algumas espécies sobrevivem no sub-bosque. Mudanças da irradiância entre estes ambientes podem afetar a morfologia foliar e a absorção da radiação fotossinteticamente ativa. Neste estudo foram avaliadas as propriedades ópticas foliares, o conteúdo de clorofila, a área foliar específica e a morfologia da superfície foliar de duas espécies de lianas jovens Canavalia parviflora Benth. (Fabaceae) e Gouania virgata Reissk (Rhamnaceae), sob diferentes regimes de luz. Plantas jovens foram cultivadas em bancadas cobertas com sombrites possibilitando intensidades luminosas correspondentes a 40\%, $10 \%$ e 1,5\% da densidade de fluxo de fótons (DFF). Plantas em radiação plena foram usadas como controle. Ambas as espécies exibiram aumentos da reflectância sob radiação plena e alterações na morfologia foliar. Reduções na irradiância induziram um aumento na absorção (decréscimo na reflectância e transmitância) nas folhas de C. parviflora no verde, devido ao maior contéudo de clorofila. Mesmo não exibindo alterações pronunciadas das propriedades espectrais, G. virgata foi superior na eficiência da absorção em relação à C. parviflora sob $40 \%, 10 \%$ e 1,5\% da densidade de fluxo de fótons (DFF). O aumento da eficiência da absorção em G. virgata ocorreu em função da maior área foliar específica (AFE) nestas condições. O conjunto de ajustes nas propriedades espectrais pode auxiliar as espécies no ganho de carbono em ambientes mais sombreados da floresta.

Palavras-chave - absorção foliar, área foliar específica, condições de luz, lianas, reflectância

\section{Introduction}

Lianas (woody vines) are conspicuous in tropical forests. They are rooted in the soil and use other plants,

1. Universidade de Campinas, Instituto de Biologia IB, Departamento de Fisiologia Vegetal. Caixa Postal 6109, 13083-970 Campinas, SP, Brasil.

2. Universidade Federal de Ouro Preto, Instituto de Ciências Exatas e Biológicas, Departamento de Ciências Biológicas, Campus Morro do Cruzeiro, 35400-000 Ouro Preto, MG, Brasil.

3._Corresponding author: sanchesmc@yahoo.com.br especially trees, as support to grow towards the forest canopy of the forest (Putz \& Mooney 1991, Holbrook \& Putz 1996). Once the lianas begin to grow on the forest floor they experience extreme differences in radiation quantity and spectral quality (Lee \& Richards 1991).

Light in tropical forests exhibits variations at both temporal and spatial scales. The environment in clearings is mostly affected by high radiation that reaches the lower vegetation strata. Furthermore, the plants in the clearings and upper canopy are subjected to high temperatures and high vapour pressure deficit (Chazdon 
et al. 1996). In contrast, plants of dense forests are exposed to high relative humidity and moderate temperatures, and the irradiance is generally reduced by the filtering effect of the canopy foliage. Leaf reflectance and transmittance are low in the visible higher after $700 \mathrm{~nm}$. Hence, light in dense forest is markedly depleted of photosynthetically active wavelengths and is enriched with far-red wavelengths (Buisson \& Lee 1993). Nevertheless, there are a wide range of gap sizes and in some cases, e.g. in small gaps, their environmental conditions can be similar to the understory conditions (Gandolfi 2000).

Among different factors that contribute to environmental variation in tropical forests, light is central to several responses such as establishment, growth, and survival (Lee et al. 1996, Souza \& Válio 2001). Based on their life history, tropical plants have been categorized in two groups: light-demanding, or pioneers, and shadetolerant species (Strauss-Debenedetti \& Bazzaz 1996). Pioneer plants germinate and survive only in clearings and light gaps, while juveniles of shade-tolerant species survive well in shaded understory (Kitajima 1996). In fact, these two groups are thought to be the extremes of a continuum of shade responses among seedlings of different tree species (Osunkoya et al. 1994, Lee et al. 1996).

Growing in the understory alters the plant development at all levels of organization, from general architecture to biochemistry (Lüttge 1997). For instance, adjustments to low irradiance may lead to alterations in leaf thickness (increase in specific leaf area), higher chlorophyll and carotenoid content per unit weight, and yet, shade leaves may be relatively more enriched in chlorophyll $b$ with relation to chlorophyll $a$, resulting in low chlorophyll $a / b$ ratio compared to sun leaves (Evans \& Poorter 2001, Souza \& Válio 2003b). All these changes should affect the leaf optical properties (Lee et al. 1990, Vogelmann 1993). Since light is often a limiting resource in the understory, one would expect that shade-tolerant species maximize the capture of light in the most efficient way, i.e., at a lower cost in terms of construction and maintenance (Lee \& Graham 1986, Poorter et al. 1995). In contrast, when plants are growing in high light environments, their leaves are usually thicker, they have thick cuticle, higher chlorophyll $a / b$ ratio and lower specific leaf area, and they are generally more vertical than shade leaves (Chiarello et al. 1987, Araus \& Hogan 1994). All these features would increase the reflectance, reducing the amount of absorbed solar energy (Tanner \& Eller 1986); it would be consequently beneficial for the leaf, as it reduces the heat and thus transpirational and photosynthetic costs (Poorter et al. 1995).

Although some studies stated that no pronounced differences were observed in leaf optical properties between sun and shade species, or between exposed and shaded leaves of a particular species (Lee \& Graham 1986, Knapp \& Carter 1998, Cao 2000), other works showed that, greater adjustments on leaf characteristics occurred, in shade tolerant species, which might increase light absorptance efficiency under limited light (Poorter et al. 1995, Souza \& Válio 2003b).

Most of these studies on leaf response to light gradient have been conducted with tree species, maybe due to their importance in the sucessional processes. However, some authors focused their attention on species that belong to other life forms, as lianas (Putz \& Mooney 1991, Avalos \& Mulkey 1999, Kazda \& Salzer 2001, Sanches \& Válio 2002). The increasing scientific interest in lianas is related to their role in forest regeneration and to their contribution to the maintenance of biodiversity and whole-forest transpiration (Restom \& Nepstad 2001, Schnitzer et al. 2000, Schnitzer \& Bongers 2002). In general, lianas have a detrimental effect on forest dynamics by reducing the growth and increasing mortality of their host (Putz 1984, PérezSalicrup \& Barker 2000). In addition, lianas contribute to increase litter production and are very important to forest animals, both as a source of food and as a structural component of their habitat (Gentry 1991).

Despite their importance, the ecophysiology of lianas is relatively poor compared to tree species. This is partly due to the difficulty in assessing the canopy, in identifying genets (sexually produced plants) or ramets (vegetatively produced plants), and also to taxonomic uncertainties, (Avalos \& Mulkey 1999, Schnitzer \& Bongers 2002).

Most lianas are lush in natural and man-made clearings because of their rapid growth in high light environments and of a large production of seeds (Putz 1984, Lüttge 1997, Dewalt et al. 2000). This distribution pattern may be a sign that these life forms need high irradiance for establishment and development. Thus lianas may share several life-history traits with pioneer species (Lüttge 1997, Schnitzer et al. 2000). The purpose of the present study is to evaluate the adjustments in leaf level along the gradient of light. We will specifically take into account the changes in leaf morphological characteristics, chlorophyll content and leaf optical properties of two liana species that naturally grow in a fragment of a tropical semideciduous forest. 


\section{Materials and methods}

Selected species - The species studied were Canavalia parviflora Benth. (Fabaceae) and Gouania virgata Reissk (Rhamnaceae). Canavalia parviflora is a twining liana, whereas Gouania virgata shows tendrils as climbing mechanism. Both lianas are widely distributed in open areas, such as forest edges and gaps, although juveniles of Gouania virgata are also found in understory environments. Both studied species were native in a semi-deciduous forest located

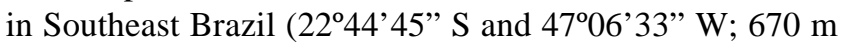
altitude; Morellato \& Leitão Filho 1996). The climate is characterized by a dry season with mild temperatures $\left(12-27^{\circ} \mathrm{C}\right)$ from April to September and a wet and warm season $\left(18-34^{\circ} \mathrm{C}\right)$ from October to March. Ripe fruits were picked up from a minimum of five plants before their natural dispersal and brought to the laboratory to separate the seeds. After cleaning, the seeds were scarified prior to the germination treatment, and seedlings were obtained from seeds germinated in Petri dishes at $25{ }^{\circ} \mathrm{C}$ under continuous white fluorescent light. Germinated seeds were transplanted to plastic pots $(0.7 \mathrm{~L})$ and maintained in the glasshouse for initial establishment.

Experimental conditions - Plants were transferred to an open area at the Universidade Estadual de Campinas. They were kept well watered during the experiments and a Hoagland solution (100 mL per pot) was added every fifteen days (Hoagland \& Arnon 1938). Plants of each species were randomly assigned to four groups of 20, disposed on workbenches positioned in the north-south direction. These workbenches were covered by different layers of neutral shade netting, thus creating three levels of light intensity corresponding to about $40 \%, 10 \%$ and $1.5 \%$ of solar irradiance. An additional irradiance level consisted of plants growing in full sun. The PAR (photosynthetically active radiation, 400-700 $\mathrm{nm}$ ) was recorded every month, by a LI-191SA line quantum sensor or an LI-190SA quantum sensor attached to a LI-1000 data logger (Li-Cor, Inc., Lincoln, NE) on cloudless days near midday. The percent level of PAR was calculated in each treatment from the full sun value. PAR, maximum and minimum air temperatures are shown in Table 1.
Leaf characteristics - Three fully-developed healthy leaves of each plant species were harvested, sealed in plastic bags, and immediately stored in a cold box to prevent water loss. Within 2 hours, they were brought to the laboratory and for their spectral properties analysed. Leaf hemispherical reflectance and transmittance of their adaxial face were measured with a LI-1800-12S integrating sphere linked by fiber optics to a LI-1800 portable spectroradiometer (LICOR), in the 400-1100 nm range with $2 \mathrm{~nm}$ step. Leaf optical properties were calibrated using a barium sulphate standard. Absorptance was calculated according to the formula: Absorptance $=1$ - reflectance - transmittance. Total absorptance was calculated separately for the wavelength range 400-700 nm (photosynthetically active radiation) and 700-750 nm (far red). Chlorophyll and carotenoid contents were measured in the same lot of plants. Five discs (diameter $=0.7 \mathrm{~cm}$ ) per plant and five plants per treatment were used for extraction. Equal samples of leaf discs were taken to obtain the dry mass. Each lot of five discs was extracted in $5 \mathrm{~mL}$ of acetone $80 \%$ during 72 hours. Then the absorbance was recorded in a spectrophotometer at 470 (carotenoids), 645 (chlorophyll $b$ ) and $663 \mathrm{~nm}$ (chlorophyll a). Chlorophyll and carotenoid content was expressed in $\mathrm{mg} \mathrm{g}^{-1}$ dry mass according to Arnon (1949) but using the absorption coefficients according to Lichtenthaler (1987). Specific leaf area (SLA) was calculated for five plants/treatment/species as the ratio area/dry mass. The leaf dry mass was obtained after drying during 48 hours at $80^{\circ} \mathrm{C}$. Scanning electron microscopy - To investigate the leaf surface (adaxial and abaxial faces), small pieces were cut, carefully fixed on aluminium stubs by double-sided adhesive tape, air-dried and splutter coated with gold. Each stub was examined and photographed in a scan electron microscope. The leaf traits were described according to Barthlott et al. (1998).

Statistical analysis - Comparison of the means from different treatments was carried out by the analysis of variance. For interactions among light treatment and species a two-way ANOVA was performed. When differences were statistically significant, the Tukey's least significant difference test, with 5\% level of probability was used (Gomes 1990).

Table 1. Photon flux density (PFD, $\mu \mathrm{mol} \mathrm{m}^{-2} \mathrm{~s}^{-1}$ ) and means of maximum (Tmax.) and minimum (Tmin.) air temperature during the experiments (October to April 2002).

\begin{tabular}{ccccc}
\hline & \multicolumn{3}{c}{ Treatment } \\
\cline { 2 - 5 }$\%$ & 100 & 40.6 & 10.2 & 1.5 \\
\hline PFD & 1728.85 & 701.92 & 176.19 & 26.60 \\
std & $( \pm 62.82)$ & $( \pm 64.88)$ & $( \pm 17.11)$ & $( \pm 9.63)$ \\
Temperature & $34.3 / 15.8$ & $34.0 / 16.0$ & $31.0 / 16.0$ & $32.0 / 16.2$ \\
max/min & $(2.25 / 3.31)$ & $(2.3 / 2.9)$ & $(0.8 / 2.6)$ & $(1.7 / 3.7)$ \\
\hline
\end{tabular}




\section{Results}

Leaves of C. parviflora Benth. and G. virgata Reissk basically showed similar patterns in their spectral properties under $100 \%$ and $40 \%$ photon flux density (PFD) (figures 1, 2). In this condition, leaves displayed strong absorptance in the range of $400-750 \mathrm{~nm}$ with a drop near $550 \mathrm{~nm}$ and a sharp decline after $700 \mathrm{~nm}$. Reflectance and transmittance showed an opposite pattern, with a small increase in $550 \mathrm{~nm}$.

Overall, reductions in irradiance induced increases in absorptance in C. parviflora leaves for wavelengths near the green region. In G. virgata leaves, this pattern was not verified. For $1.5 \%$ PFD, reductions in reflectance at $550 \mathrm{~nm}$ were the only alteration observed in $G$. virgata leaves.

Average data of absorptance, reflectance, and transmittance in the PAR $(400-700 \mathrm{~nm})$ and, far-red $(700-750 \mathrm{~nm})$ regions are gathered in table 2 . There was a significant decrease in reflectance and transmittance over the whole spectrum for $C$. parviflora leaves growing in $1.5 \%$ PFD compared to those leaves growing in full sun. Consequently, a strong absorptance was observed for this species under limited light conditions (1.5\% PFD). The effect of contrasting light regimes on spectral properties of $G$. virgata leaves was less pronounced (table 2).

Average chlorophyll and carotenoid contents for C. parviflora and $G$. virgata are given in table 3. For $10 \%$ and $1.5 \%$ PFD conditions, chlorophyll $a$, chlorophyll $b$ and total chlorophyll incresead for both species. However, this rise did not reflect alterations in chlorophyll $a / b$ ratio, except in $G$. virgata leaves grown in full sun, which showed, a smaller chlorophyll $a / b$ ratio compared to plants grown in $40 \%, 10 \%$ and $1.5 \%$ PFD. Moreover, the carotenoid content was higher under $10 \%$ and $1.5 \%$ PFD for C. parviflora leaves and under 10\% PFD for G. virgata leaves compared with full sun leaves.

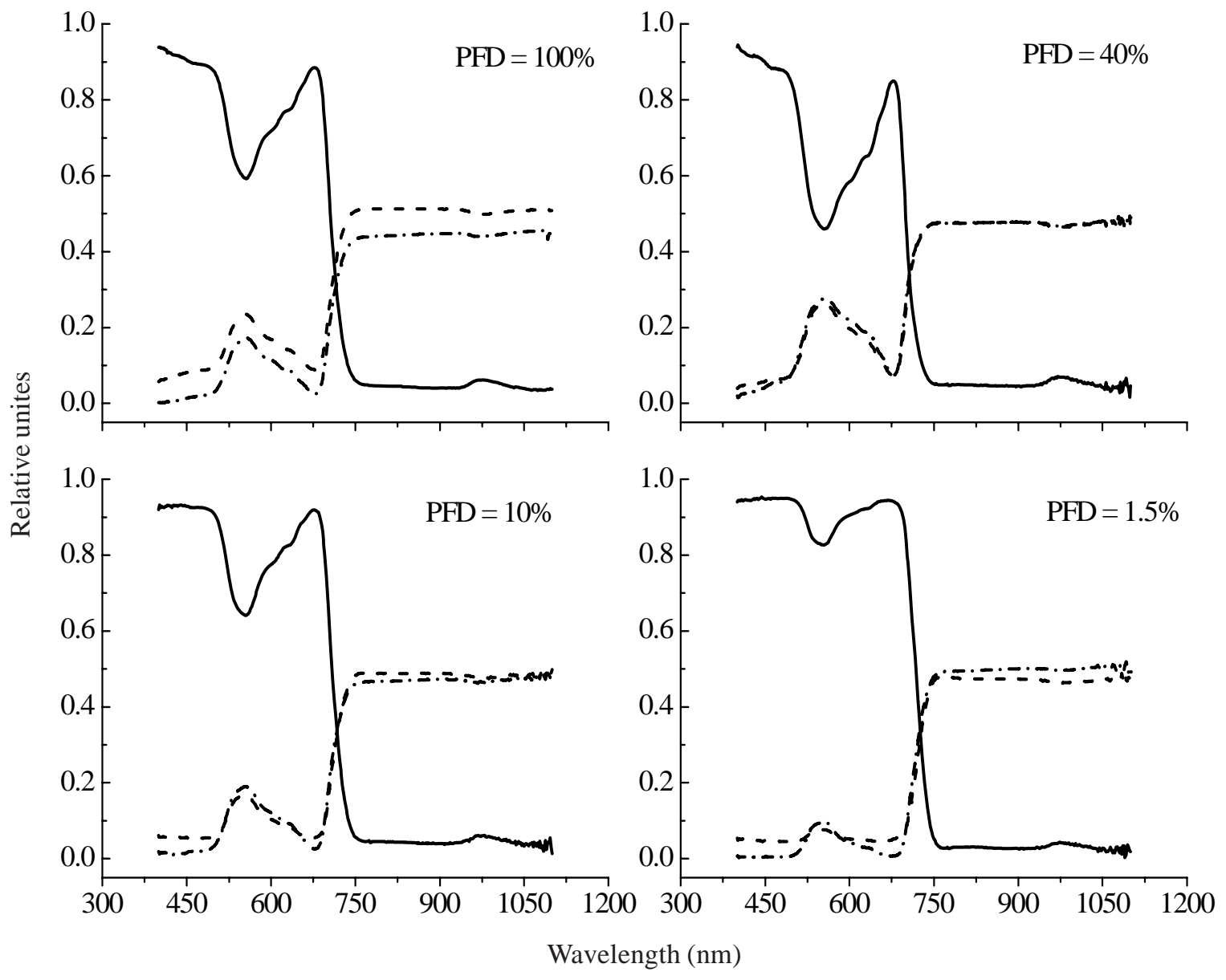

Figure 1. Spectral properties of Canavalia parviflora Benth. leaves grown under different conditions of relative irradiance. ------ = Reflectance; --.-.-. = Transmittance; - = Absorbance. 
Although high carotenoid content was observed under shade, the ratio between carotenoid and total chlorophyll (carot/chl) was higher for the two species under 100\% and $40 \%$ PFD.

Table 4 shows specific leaf area (SLA) obtained for all treatments. SLA varied as a function of light availability for C. parviflora and G. virgata leaves, both exhibiting higher SLA in 1.5\% PFD. A reduction of photosynthetic tissue may lead to higher SLA, reflecting an increased efficiency of light capture expressed as the ratio of PAR absorption to unit biomass invested in photosynthetic tissues (Poorter et al. 1995). As observed in table 2, C. parviflora was able to increase its absorption under $10 \%$ and $1.5 \%$ PFD whereas G. virgata leaves did not show any change. However, both species were more efficient to capture light under these conditions (figure 3). Absorption efficiencies were more pronounced in $G$. virgata than in C. parviflora leaves as demonstrated by significant interaction between light and species. This result was largely due

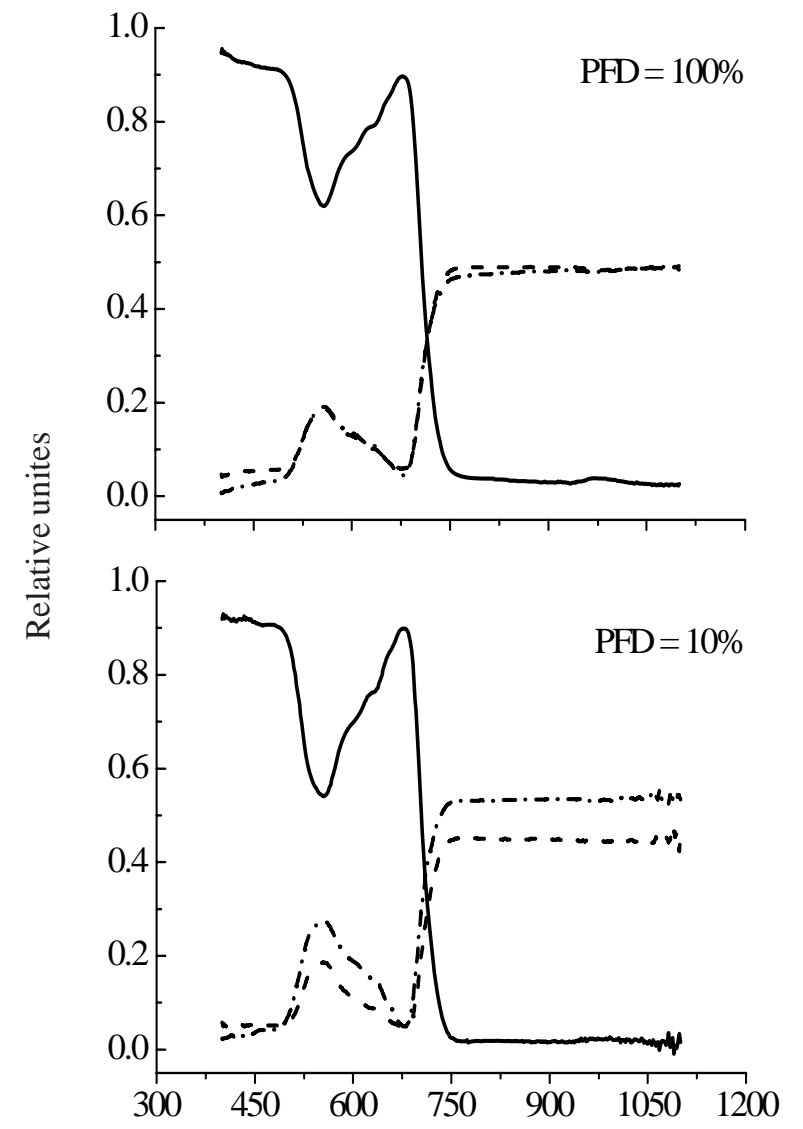

to interspecific variation in SLA, i.e., G. virgata exhibited higher SLA and was more efficient in absorption of PAR under low irradiance.

The leaf surface characteristics of $C$. parviflora and $G$. virgata are shown in figures 4 to 15 . Under full sun, the ornamentation of the C. parviflora adaxial face basically consists of folded cuticles with a relative prominent superficial sculpture (figure 4). When kept in the shade (10\% and 1.5\% PFD), one can observe the presence of glandules irregularly ordered on their surface (figure 5 and 7). C. parviflora leaves are hypostomatic. Their guard cells have thick walls, surrounded by epidermic cells with a striated cuticle. Decreases in stomatal density was observed in C. parviflora leaves under $1.5 \%$ PFD. The leaf surface in $G$. virgata growing in full sun is ornamented by many non-glandular trichomes (figure 10). On the abaxial face, the stomata are protected by trichomes. These protections are not detected on leaves in the shade (figure 13 and 15).
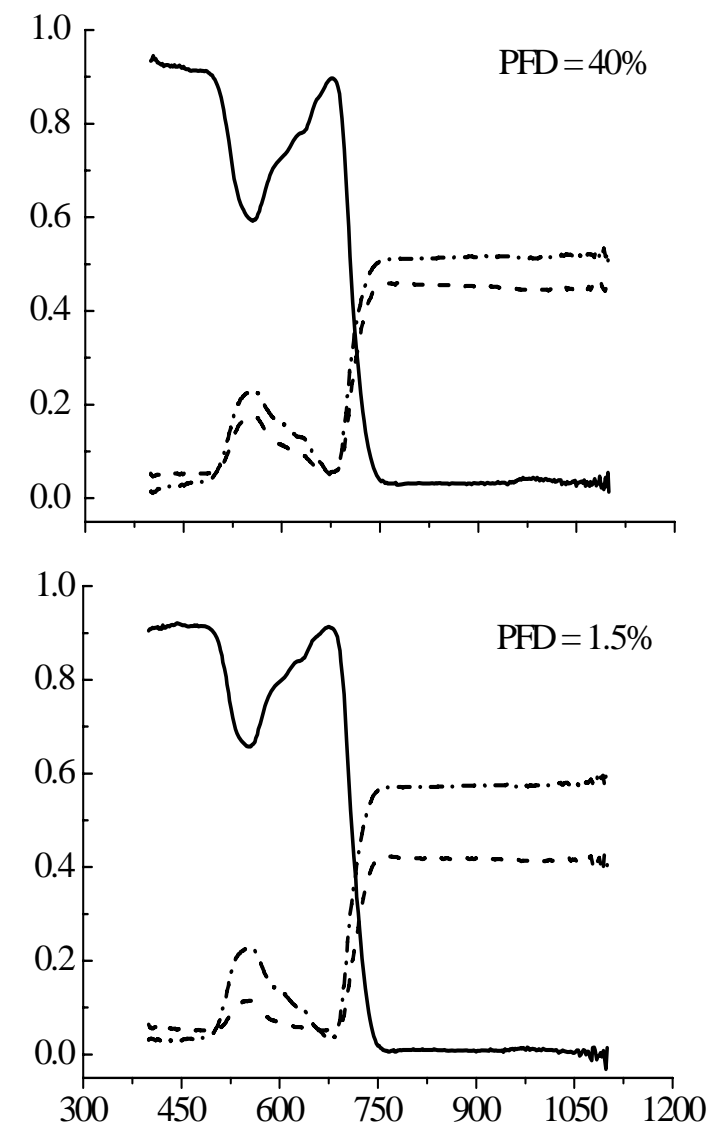

Wavelength (nm)

Figure 2. Spectral properties of Gouania virgata Reissk leaves grown under different conditions of relative irradiance. ------ = Reflectance; -.-..-.- = Transmittance; _-__ = Absorbance. 
Table 2. Average reflectance, transmittance and absorptance in the PAR (400-700 nm) and far-red (700-750) regions of the spectrum for leaves of Canavalia parviflora Benth. and Gouania virgata Reissk grown under different photon flux densities (PFD) (relative unites). In each column values followed by different letters are statistically different at the 5\% level (Tukey).

\begin{tabular}{|c|c|c|c|c|c|}
\hline Species & Wavelength(nm) & PFD (\%) & Reflectance & Transmittance & Absorptance \\
\hline \multirow{8}{*}{ C. parviflora } & $400-700 \mathrm{~nm}$ & 100 & $0.131 \mathrm{a}$ & $0.069 b$ & 0.799 bc \\
\hline & & 40 & $0.135 a$ & $0.141 \mathrm{a}$ & 0.722 c \\
\hline & & 10 & $0.086 \mathrm{ab}$ & $0.077 \mathrm{~b}$ & $0.836 \mathrm{ab}$ \\
\hline & & 1.5 & $0.053 \mathrm{~b}$ & $0.030 \mathrm{c}$ & $0.916 \mathrm{a}$ \\
\hline & $700-750 \mathrm{~nm}$ & 100 & $0.409 a$ & $0.343 b$ & 0.246 bc \\
\hline & & 40 & 0.408 a & $0.417 \mathrm{a}$ & $0.174 c$ \\
\hline & & 10 & $0.360 \mathrm{a}$ & $0.361 b$ & $0.278 \mathrm{~b}$ \\
\hline & & 1.5 & $0.292 b$ & $0.318 b$ & 0.389 a \\
\hline \multirow[t]{8}{*}{ G. virgata } & $400-700 \mathrm{~nm}$ & 100 & $0.094 \mathrm{a}$ & $0.085 a$ & $0.819 a$ \\
\hline & & 40 & 0.089 a & $0.104 \mathrm{a}$ & $0.806 \mathrm{a}$ \\
\hline & & 10 & 0.089 a & $0.123 \mathrm{a}$ & $0.787 \mathrm{a}$ \\
\hline & & 1.5 & $0.066 \mathrm{~b}$ & 0.094 a & 0.838 a \\
\hline & $700-750 \mathrm{~nm}$ & 100 & $0.375 \mathrm{a}$ & $0.370 \mathrm{~b}$ & $0.253 \mathrm{a}$ \\
\hline & & 40 & $0.354 \mathrm{a}$ & $0.414 \mathrm{ab}$ & $0.231 \mathrm{a}$ \\
\hline & & 10 & 0.348 a & $0.436 \mathrm{a}$ & $0.214 \mathrm{a}$ \\
\hline & & 1.5 & $0.291 b$ & $0.432 \mathrm{a}$ & $0.276 \mathrm{a}$ \\
\hline
\end{tabular}

Table 3. Chlorophyll and carotenoid content of leaves of Canavalia parviflora Benth. and Gouania virgata Reissk grown under different photon flux densities (PFD). Means followed by different letters in each column are statistically significant between treatments at the $5 \%$ level (Tukey).

\begin{tabular}{lccccccc}
\hline Species & $\begin{array}{c}\text { PFD } \\
\%\end{array}$ & $\begin{array}{c}\text { Chlorophyll } \\
a \\
\left(\mathrm{mg} \mathrm{g}^{-1}\right)\end{array}$ & $\begin{array}{c}\text { Chlorophyll } \\
b\end{array}$ & $\begin{array}{c}\text { Total } \\
\left(\mathrm{mg} \mathrm{g}^{-1}\right)\end{array}$ & $\begin{array}{c}a / b \\
\text { Chlorophyll }\end{array}$ & $\begin{array}{c}\text { Total } \\
\text { ratio } \\
\text { carotenoids } \\
\left(\mathrm{mg} \mathrm{g}^{-1}\right)\end{array}$ & $\begin{array}{c}\text { Carotenoids/ } \\
\text { chlorophyll } \\
\text { ratio }\end{array}$ \\
\hline C. parviflora & 100 & $2.34 \mathrm{c}$ & $1.28 \mathrm{~b}$ & $3.62 \mathrm{c}$ & $1.84 \mathrm{a}$ & $1.06 \mathrm{c}$ & $0.29 \mathrm{a}$ \\
& 40 & $3.06 \mathrm{c}$ & $1.47 \mathrm{~b}$ & $4.54 \mathrm{c}$ & $2.08 \mathrm{a}$ & $1.25 \mathrm{bc}$ & $0.27 \mathrm{a}$ \\
& 10 & $6.42 \mathrm{~b}$ & $3.86 \mathrm{a}$ & $10.28 \mathrm{~b}$ & $1.71 \mathrm{a}$ & $1.88 \mathrm{a}$ & $0.18 \mathrm{~b}$ \\
G. virgata & 1.5 & $8.96 \mathrm{a}$ & $5.05 \mathrm{a}$ & $14.02 \mathrm{a}$ & $1.77 \mathrm{a}$ & $1.57 \mathrm{ab}$ & $0.11 \mathrm{c}$ \\
& 100 & $1.73 \mathrm{c}$ & $0.90 \mathrm{c}$ & $2.63 \mathrm{c}$ & $1.87 \mathrm{~b}$ & $0.91 \mathrm{~b}$ & $0.38 \mathrm{a}$ \\
& 40 & $2.86 \mathrm{c}$ & $1.27 \mathrm{c}$ & $4.14 \mathrm{c}$ & $2.28 \mathrm{a}$ & $1.32 \mathrm{~b}$ & $0.32 \mathrm{a}$ \\
& 10 & $6.71 \mathrm{~b}$ & $2.87 \mathrm{~b}$ & $9.58 \mathrm{~b}$ & $2.33 \mathrm{a}$ & $2.14 \mathrm{a}$ & $0.22 \mathrm{~b}$ \\
& 1.5 & $8.92 \mathrm{a}$ & $4.03 \mathrm{a}$ & $12.95 \mathrm{a}$ & $2.21 \mathrm{a}$ & $1.19 \mathrm{~b}$ & $0.08 \mathrm{c}$ \\
\hline
\end{tabular}

\section{Discussion}

The effects of shade conditions caused changes in the leaf biophysical characteristics. C. parviflora leaves showed a significant absorption increase in the 400-750 nm range under 1.5\% PFD when compared to full sun. This increase was achieved through reductions in transmittance and reflectance. Similar optical properties have been verified in Hymenaea courbaril
L., a tree species considered as shade tolerant that grows in the same study area (Souza \& Válio 2001, Souza \& Válio 2003a, b). As pointed out by these authors, the increase in absorptance may be partially explained by an increase in chlorophyll content under shade and not by a thinning of the leaf. This was probably the case for C. parviflora, since this species showed higher chlorophyll content and was less responsive to specific leaf area than $G$. virgata (their leaves were thicker than 
Table 4. Specific leaf area (SLA - $\mathrm{cm}^{2} \mathrm{~g}^{-1}$ ) of Canavalia parviflora Benth. and Gouania virgata Reissk grown under different photon flux densities (PFD). Means followed by different letters are statistically significant between treatments at the 5\% level (Tukey 5\%).

\begin{tabular}{lcccc}
\hline & \multicolumn{4}{c}{ PFD \% } \\
\cline { 2 - 5 } Species & 100 & 40 & 10 & 1.5 \\
\hline C. parviflora & $146.90 \mathrm{c}$ & $184.14 \mathrm{c}$ & $323.16 \mathrm{~b}$ & $405.21 \mathrm{a}$ \\
G. virgata & $145.72 \mathrm{~d}$ & $253.33 \mathrm{c}$ & $424.68 \mathrm{~b}$ & $536.63 \mathrm{a}$ \\
\hline
\end{tabular}

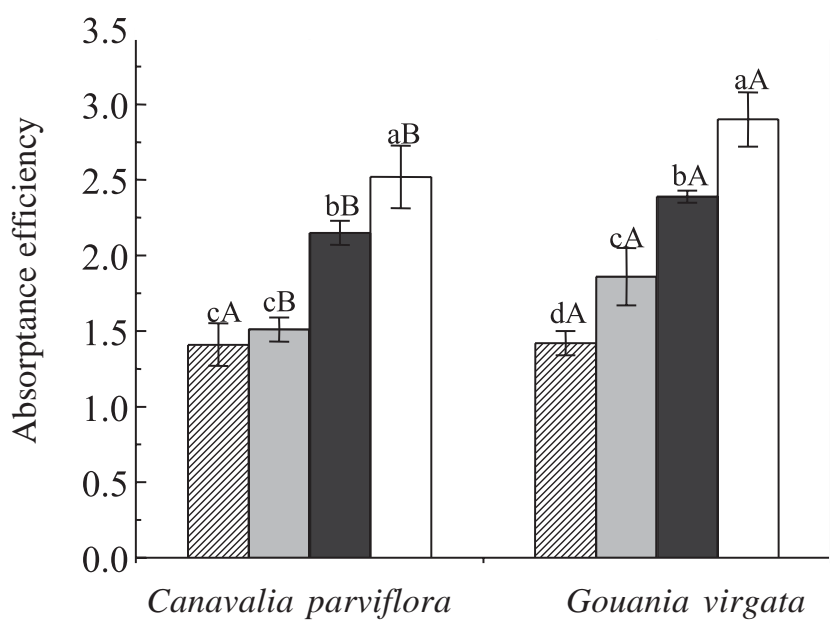

Figure 3. Absorption efficiency (ratio between absorptance in the range of PAR and photosynthetic tissue biomass). Bars represent mean standard deviation. Lowercase compare different light regimes and uppercase compare species. = $100 \%$ PFD; $\square=40 \%$ PFD; $\square=10 \%$ PFD; $\square=1.5 \%$ PFD.

G. virgata under $1.5 \%$ PFD) (data not shown). Moreover, C. parviflora also showed an increase in absorptance after $700 \mathrm{~nm}$ under $1.5 \%$ PFD, as mentioned earlier by Lee \& Graham (1986), Poorter et al. (1995) and Souza \& Válio (2003b). Considering that understory environment is more enriched with far-red wavelengths, the use of quanta in the 700-750 range may be of great value for overall carbon gain in this environment (Lee \& Graham 1986). Other features can also be related to a greater absorbance under limited light conditions. Leaves in the shade often displayed a high proportion of spongy parenchyma characterized by cells irregularly arranged at the abaxial face, contributing to the enhancement of their intercellular spaces (Lee et al. 1990). These spaces randomly scatter light within the leaf, increasing the photon pathway and then their absorption probability (Lee et al. 1990, Vogelmann 1993,
DeLucia et al. 1996). Thus, it is possible that absorption was enhanced under $1.5 \%$ PFD in C. parviflora by low-light alterations in leaf anatomy maximizing the effective pathlenght of a radiation beam (Lee \& Graham 1986, Vogelmann 1993).

Changes induced by light growth conditions on G. virgata leaf optical properties were less obvious. Despite similar values for PAR absorption under high and low light, $G$. virgata seemed to be more efficient to capture light, as demonstrated by higher ratio between PAR absorption and unit biomass when compared to C. parviflora (figure 3). This response was attained by greater variation in specific leaf area, as a result of their reduced leaf mass under $40 \%, 10 \%$ and $1.5 \%$ PFD. This species can be found in the understory of the Santa Genebra forest, where photosynthetically active radiation values range from 10 to $50 \mu \mathrm{mol} \mathrm{m} \mathrm{m}^{-2} \mathrm{~s}^{-1}$ (Gandolfi 2000). High absorption efficiency may represent an advantage in an understory environment, where carbon fixation rates are generally low and biomass use may be considered crucial (Poorter et al. 1995). In a study including several species from sun to deep shade habitats, Lee \& Graham (1986) verified a striking similarity of leaf optical properties between these groups, but the shade species were more efficient to capture light, due to differences in leaf anatomy of shade species compared to sun species.

The absorptance values measured in this study (near 80\% under 100\% PFD) are below values reported by Lee \& Graham (1986) for sun-adapted species $(\mathrm{x}=88.6 \%)$ and values found by Poorter et al. (1995) for four tree species with distinct life history patterns. However, they agree with values measured for plants adapted to arid environments (Ehleringer 1981). In seasonal forests, with a well-defined dry season, a reduced absorptance value would benefit to liana species that predominate in marginal environments, such as the edge of forests where they are exposed to high light, scarcity of water and high vapour pressure deficits. Souza \& Válio (2003b) also found mean absorptance values of $76 \%$ under full sun for tree species differing in successional status in the same area of this study. In this case, the slightly higher absorptance values for lianas compared to species investigated by Souza \& Válio (2003b) could be, with other physiological attributes, a support for their competitive growth pattern in clearings and edge gaps. Futher studies of leaf physiology under contrasting light regimes are necessary to clarify possible differences between liana and tree species.

Reduction of absorption is generally due to epidermics modifications. Structures like wax or 

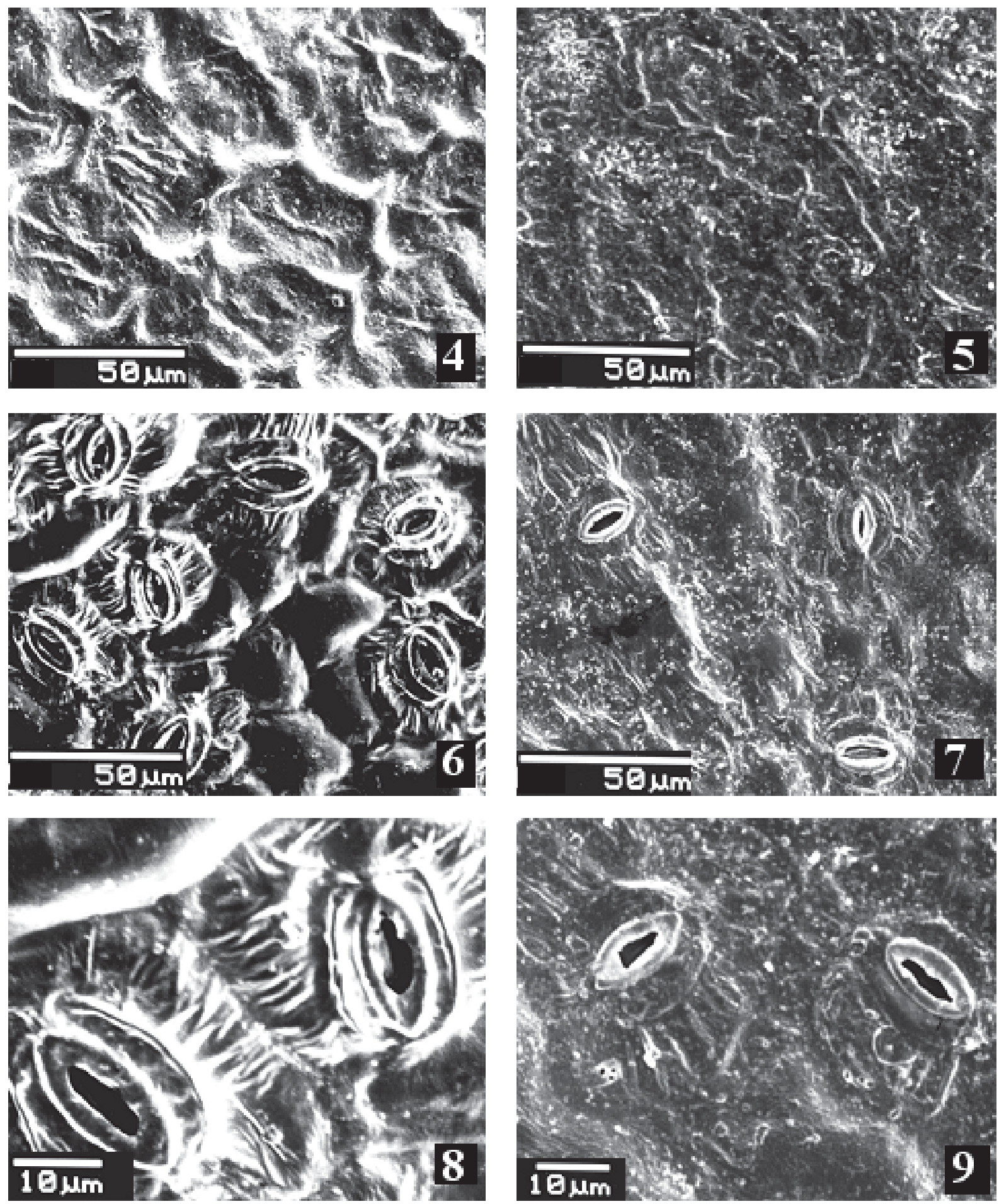

Figures 4-9. Scanning electron microscopy showing details of Canavalia parviflora Benth. leaf surface. 4. Adaxial face under full sun. 5. Adaxial face under 1.5\% RI. 6. Stomatal under abaxial face, full sun. 7. Stomatal under abaxial face, 10\% RI; 8. Stomatal under abaxial face, full sun. 9. Stomatal under abaxial face, 1.5\% RI. (RI = relative irradiance). 

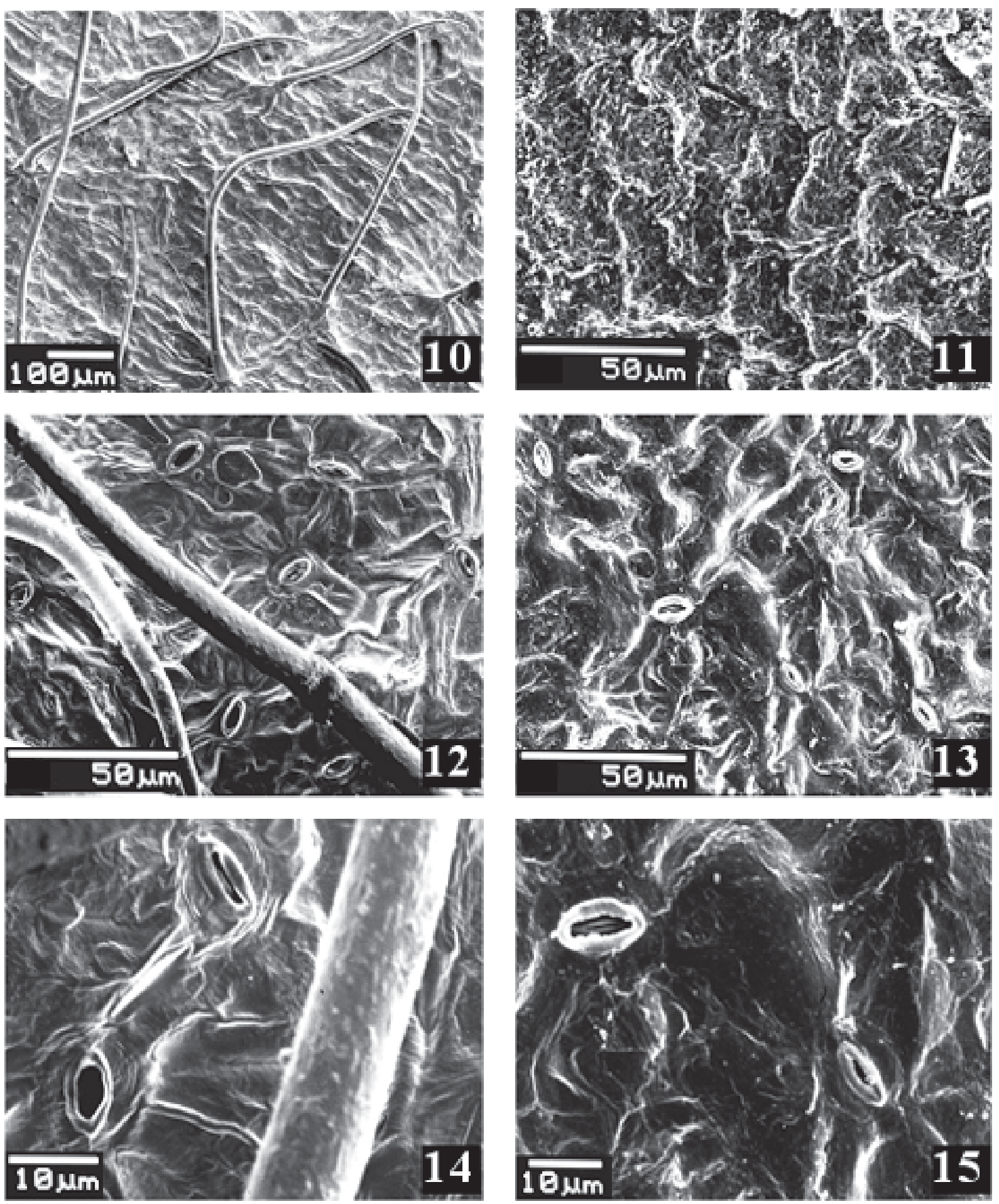

Figures 10-15. Scanning electron microscopy showing details of Gouania virgata Reissk leaf surface. 10. Adaxial face under full sun. 11. Face adaxial under 1.5\% RI. 12. Stomatal under abaxial face, full sun. 13. Stomatal under abaxial face, 10\% RI. 14. Stomatal under abaxial, full sun. 15. Stomatal under abaxial, 1.5\% RI. (RI = relative irradiance). 
trichomes are associated with higher leaf reflectance and lower absorptance (Ehleringer 1981). It has been suggested that in sunny environments, such modifications helped to limit water loss by lowering the amount of absorbed light and the consequential heat load (Vogelmann 1993, Poorter et al. 1995). The reflectance increase in both species in full sun was probably due to the presence of a dense layer of cuticle folds in C. parviflora leaves and to a high density of trichomes in G. virgata. Moreover, in full sun and 40\% PFD, $G$. virgata leaves stood erected to reduce light penetration by $50 \%$. As documented by Gamon \& Pearcy (1989), leaf movements in Vitis californica Benth. minimized the load of radiation at midday, maintaining the photosynthetic function. Thus, in $G$. virgata, the behavior that would become more subject to photoinhibition in full sun, such as reduced chlorophyll $a / b$ ratio (Araus \& Hogan 1994) might be compensated by greater thickness and changes in leaves orientation.

Changes in pigment composition under contrasting light conditions, mainly carotenoids and chlorophylls ( $a$ and $b$ ), have been reported for a large number of species (Demmig-Adams et al. 1995, Rosevear et al. 2001). Although the absolute levels of carotenoids were reduced under full sun, both species exhibited a higher carotenoid/chlorophyll ratio in full sun than in the shade. The role of carotenoids in higher plants, both as accessory light-harvesting pigments (they trap light energy and transfer it to chlorophyll) and as a protector of the photosynthetic apparatus from light-mediated stress has been emphasized (Young 1991). It is likely that a higher carotenoid content helps plants to cope with high irradiances that prevail in full sun. However carotenoids were significantly higher in $10 \%$ and $1.5 \%$ PFD, indicating also their role as an accessory pigment. One of the most common responses to light conditions is a change in the chlorophyll $a / b$ ratio (Osborne et al. 1994). Typically, the chlorophyll $a / b$ ratio decreases and the total amount of chlorophyll associated with the light harvest proteins increases in response to low irradiance, leading to a greater efficiency of light utilization (Anderson et al. 1988). In low irradiances, the structure of thylakoid changes; increases of the length of appressed to non-appressed membranes ratio are consistent with changes of chlorophyll $a / b$ ratio due to relative composition of different pigments that compose both membranes (Anderson et al. 1988). Indeed, most species grown under low irradiances present a decrease in chlorophyll $a / b$ ratio (Lee 1988, Cao 2000, Evans \& Poorter 2001). However, lianas were unusual with this trait; because, they generally exhibited enhancement of chlorophyll $a, b$ and total (mass basis) under $10 \%$ and $1.5 \%$ PFD when compared with plants growing in full sun. This increase was not followed by reductions in the chlorophyll $a / b$ ratio, indicating similar structure of thylakoid membranes and showing that although reductions on chlorophyll $a / b$ were a common response for a great number species, it is not universal (Murchie \& Horton 1997). Similarly, Mycelis muralis (L.) Dumort (Osborne et al. 1994), a herbaceous and shade-tolerant species showed constant values of chlorophyll $a / b$ ratio under contrasting light conditions. These results indicate the inability of some species to acclimate all components of the photossynthetic apparatus to light conditions. In the case of lianas, the lack of adjustment of the chlorophyll $a / b$ ratio under low irradiance may further impair their long-term survival in the understory. Nevertheless, other traits like $\mathrm{CO}_{2}$ assimilation rate, respiration rates and leaf structures may be rather more important than pigment concentration (Lee et al. 1990, Evans \& Poorter 2001).

In spite of no alteration in the chlorophyll $a / b$ ratio, both species enhanced SLA under low irradiance, with a higher effect in G. virgata. An increase in SLA has been positively correlated with lower irradiance (Lee et al. 2000, Evans \& Poorter 2001, Souza \& Válio 2003b). Greater SLA may reflect the occurrence of thin leaves: This is a common response among tree species of different successional groups (Souza \& Válio 2003b). Increase in SLA is partially attributed to size and shape of mesophyll cells and reduced Calvin cycle enzyme levels (Björkman 1981, Araus \& Hogan 1994). G. virgata was also found in understory environments, and the high SLA observed under shade conditions could contribute to produce surfaces for energy capture at lower metabolic cost (Lee \& Graham 1986, Lee et al. 1990).

Finally, both species showed adjustments in their optical properties, whether by increasing absorptance or absorptance efficiency. The latter was observed in shade-tolerant tree species (Poorter et al. 1995, Lee et al. 2000, Souza \& Válio 2003b). Hence, the predominance of lianas in environments inherent to pioneer species does not imply that their leaf physiological attributes would be similar to these plants. C. parviflora and $G$. virgata displayed different characteristics that would allow them to maintain a positive carbon balance in a gradient of light regimes. These morphological and physiological adjustments may be considered essential to lianas that experience pronounced variations in both spectral quantity and quality during their life histories (Lee \& Richards 1991). 
Acknowledgments - We thank Dr. Jurandir Zullo Junior for helping with spectroradiometer measurements and Dr. Andrea P. Spina for useful comments about leaf morphology. Fapesp and CNPq for supported this work.

\section{References}

ANDERSON, J.M., CHOW, W.S. \& GOODCHILD, D.J. 1988. Thylakoid membrane organization in sun/shade acclimation. Australian Journal Plant Physiology 15:11-26.

ARAUS, J.L. \& HOGAN, K.P. 1994. Leaf structure and patterns of photoinhibition in two neotropical palms in clearings and forest understory during the dry season. American Journal of Botany 81:726-738.

ARNON, D.I. 1949. Cooper enzyme in isolated chloroplast polyphenoloxidase in Beta vulgaris. Plant Physiology 24:1-15.

AVALOS, G. \& MULKEY, S.S. 1999. Photosynthetic acclimation of the liana Stigmaphyllon lindenianum to light changes in a tropical dry forest canopy. Oecologia 120:475-484.

BARTHLOTT, W., NEINHUIS, C., CUTLER, D., DITSCH, F., MEUSEL, I., THEISEN, I. \& WILHELMI, H. 1998. Classification and terminology of plant epicuticular waxes. Botanical Journal of the Linnean Society 126:237-260.

BJÖRKMAN, O. 1981. Responses to different quantum flux densities. In: Physiological plant ecology I encyclopedia of plant physiology (O.L. Lange, C.B. Osmond \& H. Ziegler, eds.). Springer-Verlag, Heidelberg, p.57-107

BUISSON, D. \& LEE, D.W. 1993. The developmental responses of papaya leaves to simulated canopy shade. American Journal of Botany 80:947-952.

CAO, K.-F. 2000. Leaf anatomy and chlorophyll content of 12 woody species in contrasting light conditions in a Bornean heath forest. Canadian Journal of Botany 78:1245-1253.

CHAZDON, R.L., PEARCY, R.W., LEE, D.W. \& FETCHER, N. 1996. Photosynthetic responses of tropical forest plants to contrasting light environments. In: Tropical forest plant ecophysiology (S.S. Mulkey, R.L. Chazdon \& A.P. Smith, eds.). Chapman \& Hall, New York, p.5-55.

CHIARELLO, N.R., FIELD, C.B. \& MOONEY, H.A. 1987. Midday wilting in a tropical pioneer tree. Functional Ecology 1:3-11.

DELUCIA, E.H., NELSON, K., VOGELMANN, T.C. \& SMITH, W.K. 1996. Contribution of intercellular reflectance to photosynthesis in shade leaves. Plant, Cell and Environment 19:159-170.

DEMMIG-ADAMS, B., ADAMS, W.W., LOGAN, B.A. \& VERHOEVEN, A.S. 1995. Xantophyll cycle-dependent energy dissipation and flexible photosystem II efficiency in plants acclimated to light stress. Australian Journal of Plant Physiology 22:249-260.
DEWALT, S.J., SCHNITZER, S.A. \& DENSLOW, J.S. 2000. Density and diversity of lianas along a chronosequence in a central Panamanian lowland forest. Journal of Tropical Ecology 16:1-19.

EHLERINGER, J. 1981. Leaf absorptances of mohave and sonoran desert plants. Oecologia 49:366-370.

EVANS, J.R. \& POORTER, H. 2001. Photosynthetic acclimation of plants to growth irradiance: the relative importance of specific leaf area and nitrogen partitioning in maximizing carbon gain. Plant, Cell and Environment 24:755-767.

GAMON, J.A. \& PEARCY, R.W. 1989. Leaf movement, stress avoidance and photosynthesis in Vitis californica. Oecologia 79:475-481.

GANDOLFI, S. 2000. História natural de uma floresta semidecidual no interior de São Paulo, SP. Tese de doutorado. Universidade Estadual de Campinas, Campinas.

GENTRY, A.H. 1991. The distribution and evolution of climbing plants. In: The biology of vines (F.E. Putz \& H.A. Mooney, eds.). Cambridge University Press, Cambridge, p.3-49.

GOMES, P. F. 1990. Curso de Estatística Experimental. 13 ${ }^{\mathrm{a}}$ ed. Livraria Nobel, Piracicaba.

HOAGLAND, D.R. \& ARNON, D.I. 1938. The water-culture method for growing plants without soil. Berkeley, University of California. Agricultural Experiment Station.

HOLBROOK, N.M. \& PUTZ, F.E. 1996. Physiology of tropical vines and hemiepiphytes: Plants that climb up and plants that climb down. In: Tropical forest plant ecophysiology (S.S. Mulkey, R.L. Chazdon \& A.P. Smith, eds.). Chapman \& Hall, New York, p.363-394.

KAZDA, M. \& SALZER, J. 2000. Leaves of lianas and selfsupporting plants differ in mass per unit area and in nitrogen content. Plant Biology 2:268-271.

KITAJIMA, K. 1996. Ecophysiology of tropical tree seedlings. In: Tropical forest plant ecophysiology (S.S. Mulkey, R.L. Chazdon \& A.P. Smith, eds.). Chapman \& Hall, New York, p.559-596.

KNAPP, A.P. \& CARTER, G.A. 1998. Variability in leaf optical properties among 26 species from a broad range of habitats. American Journal of Botany 85:940-946.

LEE, D.W. 1988. Simulating forest shade to study the developmental ecology of tropical plants: juvenile growth in three vines in India. Journal of Tropical Ecology 4:281-292.

LEE, D.W. \& GRAHAM, R. 1986. Leaf optical properties of rainforest sun and extreme shade plants. American Journal of Botany 73:1100-1108.

LEE, D.W. \& RICHARDS, J.H. 1991. Heteroblastic development in vines. In: In: The biology of vines (F.E. Putz \& H.A. Mooney, eds.). Cambridge University Press, Cambridge p.205-243. 
LEE, D.W., BONE, R.A., TARSIS, S.L. \& STORCH, D. 1990. Correlates of leaf optical properties in tropical forest sun and extreme-shade plants. American Journal of Botany 77:370-380.

LEE, D.W., KRISHNAPILAY, B., MANSOR, M., MOHAMAD, H. \& YAP, S.K. 1996. Irradiance and spectral quality affect asian tropical rain forest tree seedling development. Ecology 77:568-580.

LEE, D.W., OBERBAUER, S.F., JOHNSON, P., KRISHNAPILAY, B., MANSOR, M., MOHAMAD, H. \& YAP, S.K. 2000. Effects of irradiance and spectral quality on leaf structure and function in seedlings of two Southeast Asian Hopea (Dipterocarpaceae) species. American Journal of Botany 87:447-455.

LICHTENTHALER, H. 1987. Chlorophylls and carotenoids: pigments of photosynthetic biomenbranes. Methods in Enzimology 148:351-383.

LÜTTGE, U. 1997. Physiological ecology of tropical plants. Springer-Verlag, Berlin.

MORELLATO, L.P.C. \& LEITÃO FILHO, H.F. 1996. Reproductive phenology of climbers in a Southeastern Brazilian forest. Biotropica 28:180-191.

MURCHIE, E.H. \& HORTON, P. 1997. Acclimation of photosynthesis to irradiance and spectral quality in British plant species: chlorophyll content, photosynthetic capacity and habitat preference. Plant, Cell and Environment 20:438-448.

OSBORNE, B.A., CLABBY, G.T., HORSLEY, D. \& NOLAN, P.F. 1994. Is acclimation required for success in high light environments? A case study using Mycelis muralis (L.) Dumort (Asteraceae). New Phytologist 127:363-375.

OSUNKOYA, O.O., ASH, J.E., HOPKINS, M.S. \& GRAHAM, A.W. 1994. Influence of seed size and seedling ecological attributes on shade-tolerance of rain-forest tree species in northern Queensland. Journal of Ecology 82:149-163.

PÉREZ-SALICRUP, D. \& BARKER, M.G. 2000. Effect of liana cutting on water potential and growth of adult Senna multijuga (Caesalpinoideae) trees in a Bolivian tropical forest. Oecologia 124:469-475.

POORTER, L., OBERBAUER, S.F. \& CLARCK, D.B. 1995. Leaf optical properties along a vertical gradient in a tropical rain forest canopy in Costa Rica. American Journal of Botany 82:1257-1263.

PUTZ, F.E. 1984. The natural history of lianas on Barro Colorado Island, Panama. Ecology 65: 1713-1724.
PUTZ, F.E. \& MOONEY, H.A. 1991. The biology of vines. Cambridge University Press, Cambridge.

RESTOM, T.G. \& NEPSTAD, D.C. 2001. Contribution of vines to the evapotranspiration of a secondary forest in eastern Amazonia. Plant and Soil 236:155-163.

ROSEVEAR, M.J., YOUNG, A.J. \& JOHNSON, G.N. 2001. Growth conditions are more important than species origin in determining leaf pigment content of British plant species. Functional Ecology 15:474-480.

SANCHES, M.C. \& VÁLIO, I.F.M. 2002. Seedling growth of climbing species from a southeast Brazilian tropical forest. Plant Ecology 154:51-59.

SCHNITZER, S.A. \& BONGERS, F. 2002. The ecology of lianas and their role in forests. Trends in Ecology and Evolution 17:223-230.

SCHNITZER, S.A., DALLING, J.W. \& CARSON, W.P. 2000. The impact of lianas on tree regeneration in tropical canopy gaps: evidence for an alternative pathway of gap-phase regeneration. Journal of Ecology 88:655-666.

SOUZA, R.P. \& VÁLIO, I.F.M. 2001. Seed size, seed germination and seedling survival of Brazilian tropical tree species differing in successional status. Biotropica 33:447-457.

SOUZA, R.P. \& VÁLIO, I.F.M. 2003a. Seedling growth of fifteen Brazilian tropical tree species differing in successional status. Revista Brasileira de Botânica 26:35-47.

SOUZA, R.P. \& VÁLIO, I.F.M. 2003b. Leaf optical properties as affected by shade in saplings of six tropical tree species differing in successional status. Brazilian Journal Plant Physiology 15:49-54.

STRAUSS-DEBENEDETTI, S. \& BAZZAZ, F.A. 1996. Photosynthetic characteristics of tropical trees along successional gradients. In: Tropical forest plant ecophysiology (S.S. Mulkey, R.L. Chazdon \& A.P. Smith, eds.). Chapman \& Hall, New York, p.162-186.

TANNER, V. \& ELLER, B.M. 1986. Epidermis Structure and its significance for the optical properties of leaves of the Mesembryanthemaceae. Journal Plant Physiology 125:285-294.

VOGELMANN, T.C. 1993. Plant tissue optics. Annual Review Plant Physiology and Plant Molecular Biology 44:231-251.

YOUNG, A.J. 1991. The photoprotective role of carotenoids in higher plants. Physiologia Plantarum 83:702-708. 